
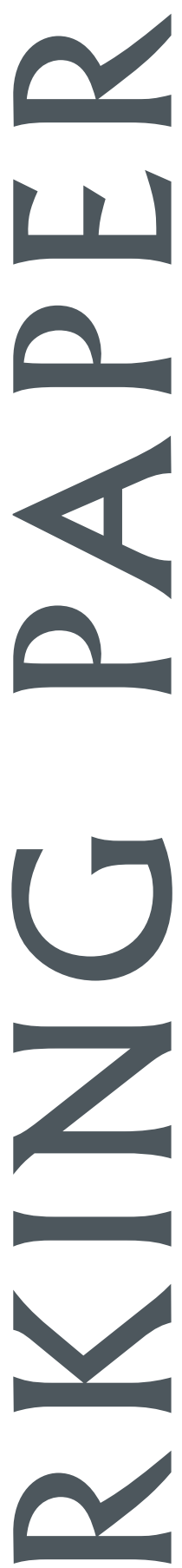

EAST-WEST CENTER 
The U.S. Congress established the East-West Center in 1960 to foster mutual understanding and cooperation among the governments and peoples of the Asia Pacific region including the United States. Funding for the Center comes from the U.S. government with additional support provided by private agencies, individuals, corporations, and Asian and Pacific governments.

East-West Center Working Papers are circulated for comment and to inform interested colleagues about work in progress at the Center.

For more information about the Center or to order publications, contact:

Publication Sales Office

East-West Center

1601 East-West Road

Honolulu, Hawaii 96848-1601

Telephone: 808-944-7145

Facsimile: 808-944-7376

Email: ewcbooks@EastWestCenter.org

Website: www.EastWestCenter.org 


\title{
The Experience of European Integration and the Potential for Northeast Asian Integration
}

\author{
Philippe C. Schmitter and Sunhyuk Kim
}

Philippe C. Schmitter was a POSCO Visiting Fellow at the East-West Center July-August 2004 and Professor of political and social sciences at the European University Institute in Florence. He was formerly a Professor at Stanford University and the University of Chicago. He is the author of numerous books, including Autonomy or Dependence as Regional Integration Outcomes, and Mexico and Latin American Economic Integration. He is the editor of several books, including Governing Capitalist Economies, and Transitions from Authoritarian Rule.

Sunhyuk Kim is Associate Professor in political science at Korea University and a former Professor at University of Southern California. He is the author of The Politics of Democratization in Korea: The Role of Civil Society.

East-West Center Working Papers: Politics, Governance, and Security Series is an unreviewed and unedited prepublication series reporting on research in progress. The views expressed are those of the author and not necessarily those of the Center. Please direct orders and requests to the East-West Center's Publication Sales Office. The price for Working Papers is $\$ 3.00$ each plus shipping and handling. 


\title{
THE EXPERI ENCE OF EUROPEAN I NTEGRATI ON \\ AND \\ THE POTENTI AL FOR NORTHEAST ASI AN I NTEGRATION
}

\author{
Philippe C. Schmitter \\ Istituto Universitario Europeo \\ and \\ Sunhyuk Kim \\ Korea University
}

The recent experience of Europe with efforts at integrating - peacefully and voluntarilypreviously sovereign national states into a single transnational organization, the European Union, is by far the most significant and far-reaching among all attempts at regionalism. It is, therefore, the most likely to provide some lessons for those world regions that are just beginning this complex and historically unprecedented process.

In the case of the Northeast Asian Region (NEAR), the creation of a transnational association, community or union - not to mention, federation-is still a very hypothetical notion. While it continues to be the case in Europe that no one knows for sure where it will end, in the case of the NEAR no one as yet knows where, when, and if it will begin!

\section{PART I: THEORIES TO BE EXPLORED ${ }^{1}$}

We have only one instrument that can help us to transfer knowledge and lessons from one region to the other: theory. Only by capturing the generic concepts, confirmed hypotheses, and observed processes underlying the European experience can we expect to make any contribution to understanding the conditions under which Northeast Asian "community formation" might succeed. And, even then, given the substantial differences in cultural norms, historical experiences, social structures, geo-strategic location and political regimes, there are abundant reasons to be cautious when transferring such lessons - as we shall see.

Unfortunately, there exists no dominant theory of why and how European regional integration works. It is surprising that a process that has been studied in such concrete detail continues to generate such abstract controversy. There is relatively little disagreement over the facts or even over the motives of actors, but there is still no single theory that can adequately explain the dynamics (or even the statics) of such a complex process of change in the relationship between previously sovereign national states and persistently more interdependent national economies.

The theory or, better, approach that I have been associated with and the one that I shall primarily draw upon in Part II for formulating lessons concerning the NEAR is something called "neo-functionalism." It places major emphasis on the role of non-state actors-especially, the "secretariat" of the regional organization involved and those interest associations and social movements that form at the level of the region - in providing the dynamic for further integration. Member states remain important actors in the process. They set the terms of the initial agreement, but they do not exclusively determine the direction and extent of subsequent change. Rather, regional bureaucrats in league with a shifting set of self-organized interests and passions seek to exploit the inevitable "spill-overs" and "unintended consequences" that occur when states agree to assign some degree of supranational responsibility for accomplishing a limited task and then discover that satisfying that function has external effects upon other of their interdependent

1 The following part contains segments drawn from my article, "Neo-Neofunctionalism" in A. Wiener, T. Diez (eds.) European Integration Theory (Oxford: Oxford University Press, 2004), pp. 45-74 
FIGURE 1:

THEORIES OF REGIONAL INTEGRATION, ONTOLOGY X EPISTEMOLOGY

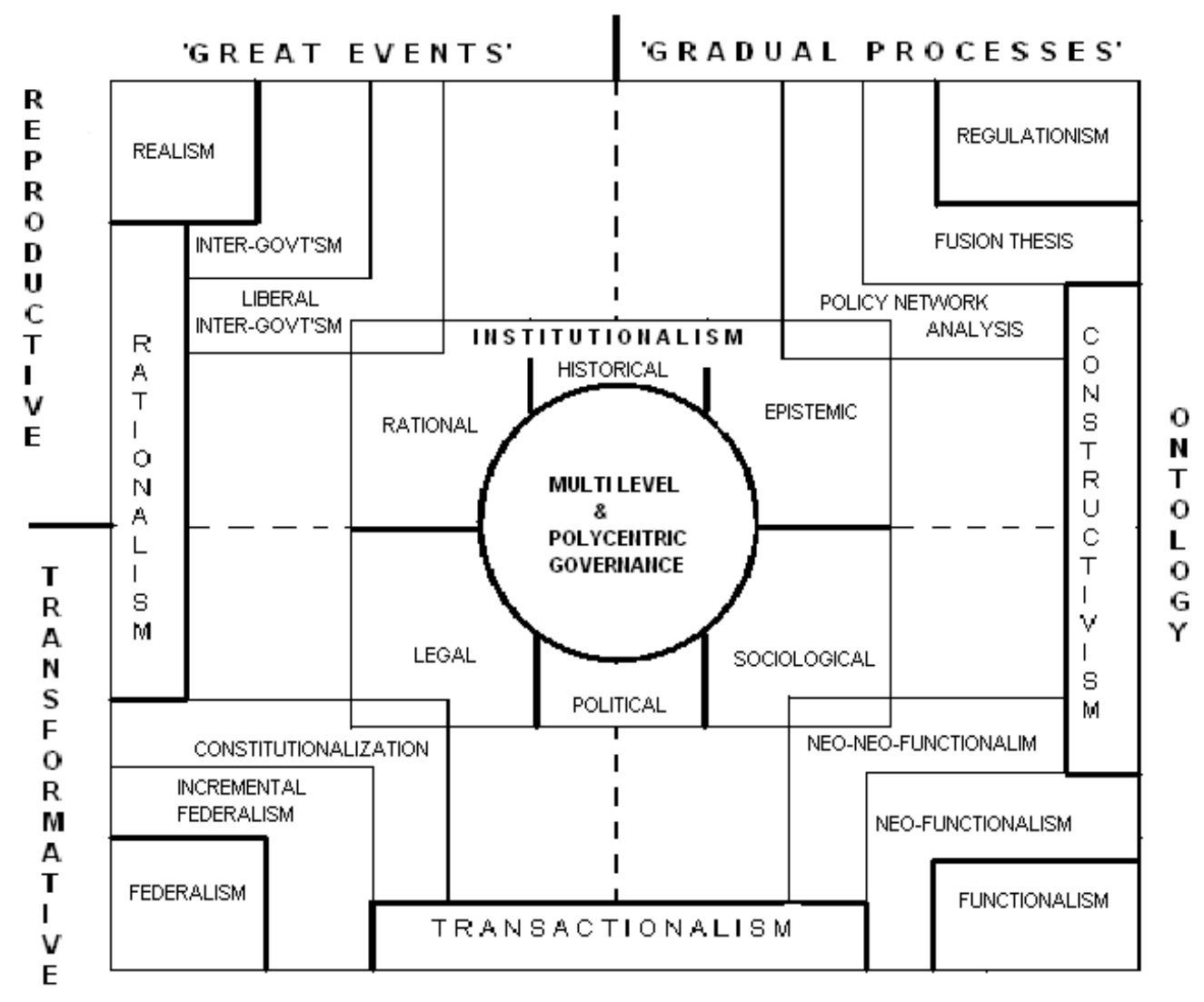

EPISTEMOLOGY

activities. According to this theory, regional integration is an intrinsically sporadic and conflictual process, but one in which, under conditions of democracy and pluralistic representation, national governments will find themselves increasingly entangled in regional pressures and end up resolving their conflicts by conceding a wider scope and devolving more authority to the regional organizations they have created. Eventually, their citizens will begin shifting more and more of their expectations to the region and satisfying them will increase the likelihood that economic-social integration will "spill-over" into political integration. ${ }^{2}$

2 Locus classicus is Ernst B. Haas, The Uniting of Europe (Stanford: Stanford University Press, 1958), followed by his more systematic presentation of its assumptions, concepts and hypotheses in Chapters 1 \& 2 of his 
Among those studying the EEC/EC/EU, neo-functionalism is, by no means, uncontested in its capacity to explain ex post or to capture ex ante the sinuous path of European integration. Indeed, it has been one of the most frequently misunderstood, caricatured, pilloried, and rejected of all of their theories. To the extent that there is a dominant theory among North American political scientists, it tends to be something called "intergovernmentalism"-probably, because most of those in the USA who have examined the EU have approached it from the perspective of international relations where the reigning orthodoxy, neo-realism, translates almost without modification into the idiom and assumptions of intergovernmentalism. From this perspective, the message is simple: power matters and state power matched to national interest matters absolutely! The direction and pace of regional integration will be determined by the interaction of sovereign national states, which not only control the initiation of the integration process but also all of its subsequent stages. Whether the process moves forward or backward or stagnates depends on calculations of national interest and the relative power that can be brought to bear on any specific issue. Under no conceivable circumstances could this process transform the nature of its member states. Indeed, its purpose is to strengthen not weaken those states. ${ }^{3}$

Europeans have tended to approach the EU more frequently from the perspective of comparative politics, and this helps to explain why they opt for other approaches - while not agreeing on a dominant one. For example, the original approach after World War II was federalism borrowed, one must admit, from the American experience. Long confined to the margin as an item of ideological wishful thinking, it has recently been revived with the convocation by the EU of a Convention on the Future of European Institutions and the drafting of a so-called Constitutional Treaty. ${ }^{4}$ A fourth "generic" approach currently well represented in Europe places its emphasis on the regulatory nature of EU policies. Interestingly, it too draws much of its inspiration from the US or, better, from the national government's practice of "independent regulatory agencies," but projects its notions and observations to the supranational level. It shares with neo-functionalism the attention to micro- and meso-exchanges between sub-national actors, eschewing the exclusive emphasis that intergovernmentalism gives to treaties or that federalism gives to constitutions, but it denies any transformative potential. Supranational regulation is seen as a technocratic imperative generated by highly interdependent economies and societies, but not something that changes the basic nature or autonomy of national politics. ${ }^{5}$

However, as one can see in Figure 1, there are many other candidates for the job of explaining and, thereby, producing generic lessons about regional integration. Especially since it was re-launched in the mid-1980s with the Single European Act, the EU has become once again a very lively site for theoretical speculation. Hardly a year does not pass that someone does not come up with a new theory and, even more surprisingly, manages to convince another group of other scholars to produce a collective volume extolling its virtues. "international regime analysis," "the regulatory approach," "liberal intergovernmentalism," "the policy-network approach," "the FusionThesis," "multi-level governance," "institutionalism," "rationalism," "constructivism,"

Beyond the Nation-State: Functionalism and International Organization (Stanford: Stanford University Press, 1964). On at least two different occasions, Haas disavowed his creation: "The Study of Regional Integration: Reflections on the Joy and Anguish of Pretheorizing," in Leon N. Lindberg and Stuart A. Scheingold (eds.), Regional Integration: Theory and Research (Cambridge, MA: Harvard University Press, 1971), pp. 3-44; ibidem, The Obsolescence of Regional Integration (Berkeley: Institute of International Studies, 1975). More recently, I have foolishly attempted to revive it in the article cited above.

3 Just at neo-functionalism could be labeled "the Berkeley Theory" of regional integration, intergovernmentalism has been consistently associated with scholars from Harvard University. Stanley Hoffmann, "Obstinate or Obsolete? The Fate of the Nation State and the Case of Western Europe," Daedalus 95 (1966) was the opening salvo, and the most recent one has been Andrew Moravsck, The Choice for Europe: Social Purpose and State Power from Messina to Maastricht (London: UCL Press, 1998).

4 Michael Burgess, Federalism and European Union: Political Ideas, Influences and Strategies in the European Community (London: Routledge, 1989) is considered the standard (if out-dated) statement on the theme.

5 Giandomenico Majone, “A European Regulatory State?” in J. Richardon (ed.), European Union: Power and Policy-Making (London: Routledge, 1996) is considered as the best statement of this argument. 
"reflectivism" and "post-modernism" have all followed each other over the past years and managed to find themselves a place somewhere in Figure 1.

Nor are these disputes over concepts and assumptions purely academic. As we shall see, one is likely to draw very different lessons for other world regions from each of these theories/approaches. One of the main tasks of any scholar trying to assess the prospects of integration in the NEAR will be to select that theory (or theories) in Figure 1 that is (are) most apposite for the peculiar conditions of that embryonic region.

In my opinion, all theories of regional integration can be placed somewhere within a two dimensional property space formed by the following variables:

1. Ontology: whether the theory presumes a process that reproduces the existing characteristics of its member-state participants and the interstate system of which they are a part, or presumes a process that transforms the nature of these sovereign national actors and their relations with each other; and

2. Epistemology: whether the evidence gathered to monitor these processes focuses primarily on dramatic political events, or upon prosaic socio-economic-cultural exchanges.

Figure 1 fills that property space with real-live "isms" that have been applied at different moments in time and from different disciplinary perspectives to explaining the dynamics (and statics) of the EU. Appropriately, we find functionalism with its neo- and neo-neo-versions in the bottom right-hand corner of the plot. Its ontology is transformative in that it assumes that both actors and the "games they play" will change significantly in the course of the integration process; its epistemology is rooted in the observation of gradual, normal and (by and large) unobtrusive exchanges among a wide range of actors. Its historic opponent, realism with its pure intergovernmental and liberal intergovernmental modifications, is diametrically opposite since its key assumptions are that dominant actors remain sovereign national states pursuing their unitary national interests and controlling the pace and outcome through periodic revisions of their mutual treaty obligations. Federalism is another transformative option, but it too relies on episodic "moments" at which a multitude of actors (and not just their governments) agree upon a new constitutional format. Its diametrical opposite is what I have labeled "regulation-ism." It shares with intergovernmentalism the presumption of fundamental continuity in actors with only a shift upward in the level at which regulation occurs. The member-states, however, remain the same as does their motivation and their predominant influence over the process. The empirical focus differs in that, like functionalism, it emphasizes almost exclusively socio-economic exchanges and the "normal" management of their consequences.

In the center of the property space of Figure One, we find an enormous and amorphous thing called "institutionalism." Most of the growth in recent theorizing about European and regional integration more generally proudly proclaims itself as such --and then immediately alerts the reader to the fact that there are many different versions of "it." By my account, there are six: (1) a "rational" one that overlaps loosely with liberal intergovernmentalism in its insistence on unitary actors, marginalist calculations and credible commitments; (2) a "legal" one that stresses the gradual but intrusively federalist role of juridical decisions and precedents; (3) a "historical" one that emphasizes the "stickiness" of identities and the "path-dependency" of institutions, but is not insensitive to less obtrusive processes of change; (4) an "epistemic" one that focuses on the normative and professional communities that cluster around specific issues-arenas and influence the making and implementing of regulations; (5) a "political" one that locates a source of potential transformation in the interpersonal networking of key politicians and their relative autonomy from followers; and, finally (6) a "sociological" one that overlaps with neo-neo-functionalism in its 
emphasis on the formation of transnational class, sectoral and professional associations and the contestation generated by global and regional social movements. Whether any or all of these deserve the prestigious title of "theory" is a matter of dispute. Institutionalism, as such, has only minimal content ("institutions matter" seems to capture and exhaust it), but some of its sub-types at least deserve the label of an approach.

In the very center of that amorphous thing in Figure 1 called "institutionalism" comes "Multi-Level Governance (MLG)." MLG can be defined as an arrangement for making binding decisions that engages a multiplicity of politically independent but otherwise interdependent actors - private and public - at different levels of territorial aggregation in more-or-less continuous negotiation/deliberation/ implementation, and that does not assign exclusive policy compétence or assert a stable hierarchy of political authority to any of these levels.

I prefer also to stress the "poly-centric" as well as the "multi-level" nature of the EU in order to include the functional dimension along with the territorial one. A Poly-Centric Governance (PCG) can be defined as an arrangement for making binding decisions over a multiplicity of actors that delegates authority over functional tasks to a set of dispersed and relatively autonomous agencies that are not controlled — de jure or de facto-by a single collective institution.

MLG has become the most omnipresent and acceptable label one can stick on the contemporary EU. Even its own politicians use it! My hunch is that its popularity among theorists can be attributable to its descriptive neutrality and, hence, its putative compatibility with virtually any of the institutionalist theories and even several of their more extreme predecessors. For politicians, it has the singular advantage of avoiding the controversial term: "state" (especially, "supranational state") and, therefore, sounds a lot less forbidding and threatening. For example, the emergence of the MLG+PCG from the process of European integration can be explained (in part) by almost all of the theories in Figure 1.

\section{PART II : LESSONS TO BE (CAUTI OUSLY) TRANSFERRED}

The "lessons" sketched out below have been drawn, primarily but not exclusively, from a neo-functionalist "reading" of the sinuous course of European integration. I am still convinced that this approach offers the best understanding of its long-term processes - with one, very important, caveat. The initiation of regional integration clearly requires an explicit agreement among governments. No one can deny that the institutions and compétences that they endow it with initially will have a continuous impact on its subsequent trajectory. Moreover, there is a high likelihood that the national states that agree to such a founding treaty will do so with the expectation that it will protect and even strengthen their sovereignty, not transform it. What happens subsequently, once the process of integration has kicked in and begun to generate its intended and unintended consequences can be quite another matter.

1. Regional integration is a process not a product. Once it has begun, the peaceful and voluntary integration of previously sovereign national states can proceed in a multitude of directions and produce secondary and tertiary effects not imagined by those who initiated it. Precisely because it has been such an infrequent occurrence, no one can predict how far it will go and what its eventual result will be. Moreover, once national states have made a serious commitment to forming a "region," they are very likely to change their motives for doing so. They may begin with security and geo-strategic reasons (Western Europe did so) and then find other applications for their "joint venture," i.e. economic prosperity and, more recently and more conflictually, unity of political action. There is no assurance that the initial effort will succeed (indeed, most attempts at regional integration have failed). Depending on conditions prevailing within and between member states, it can just as well "spill-back" as "spill-over" - to use the jargon of neo-functionalism. However, under certain conditions (and Western Europe seems to have fulfilled them), actors are more likely to resolve the inevitable conflicts of interest that emerge from the integration process by enlarging 
the tasks and expanding the authority of their common, supranational institutions. This, in essence, is the core of the neo-functionalist approach.

\section{Regional Integration has to begin somewhere and the best place to do so under contemporary conditions is with a functional area that is of relatively low political visibility, that can apparently be dealt with separately and that can generate significant benefits for all} participants. After experimenting unsuccessfully with the "direct" route to integration via common political or military institutions, the Europeans tried a second-best, indirect one - and it has (more or less) worked. The contemporary point of departure is likely to be different (the Europeans started with coal and steel; no one today would even think of this combination), but the strategy is well captured by Jean Monnet's phrase: "Petits Pas, Grands Effets," loosely translated as, "Take small steps that will lead to large effects." One wants a concrete task that can be jointly managed with little initial controversy, but which is sufficiently linked to others (engrenage is the inside term for this) so that it generates secondary effects upon other areas of potential joint cooperation. The gamble is that the conflicts generated by trying to fulfill this initial task will be resolved positively. In the case of the EU, sectoral integration was followed by trade liberalization and the Common Agricultural Program and, only belatedly, by monetary integration. Elsewhere, the sequence may be different, but the important point is the need to start out with something that involves cooperation to solve concrete problems in a positive fashion. Trade liberalization alone, so-called "free trade areas" (FTAs), is very unlikely to produce such "spill-over" effects. ${ }^{6}$

3. Regional integration is driven by the convergence of interests, not by the formation of an identity. International regions are artificial constructs. They are produced not found. Some of the clusters of national states that share the most in terms of language, religion, culture and historical experience have been the least successful in creating and developing organizations for regional integration, e.g. the Middle East and North Africa, West and East Africa, Central and South America. Ironically, it has been Europe with its multiple languages, firmly entrenched national cultures and dreadful experience with armed conflict that has proceeded the furthest - although it is important to note that the process of its regional integration has become increasingly controversial and no one has yet been able to discern where, when, and with whom it will end. If nothing else, the EU demonstrates that it has been possible "to make Europe without Europeans." Those who anticipated that concerted effort at solving concrete problems, increased economic interdependence or facilitated social communication across national borders would produce a decline in national identities and an upward shift in loyalties have been frustrated. Granted that the salience of national identities has declined (except when it comes to football matches) and that Europeans seem comfortable with multiple, nested identities that also descend to the sub-national as well as ascend to the supranational level. Granted also that the personal life styles, modes of social behavior and norms of political action have converged within Europe. Whether this has been the product of the integration process or of a broader worldwide diffusion centered on the US is a matter of dispute. Those such as Ernst Haas who foresaw a shift in loyalty to the supranational level are bound to be disappointed; those such as myself who only expected a shift in attention to the EU level are satisfied when integration inserts an enduring and significant focus of interest. Who knows how, when or even whether regionalism will transcend national identities, the important thing in the

\footnotetext{
6 Elsewhere, I have defined this "spill-over hypothesis" in the following way: "Tensions from the global environment and/or contradictions generated by past performance (within the organization) give rise to unexpected performance in pursuit of agreed-upon objectives. These frustrations and/or dissatisfactions are likely to result in the search for alternative means for reaching the same goals, i.e. to induce actions to revise their respective strategies vis-a-vis the scope and level of regional decisionmaking". Philippe C. Schmitter. "A Revised Theory of Regional Integration" in Leon Lindberg and Stuart Scheingold (eds.), Regional Integration: Theory and Research (Cambridge, MA: Harvard University Press, 1970), p. 243.
} 
meantime is that Europeans know, understand and accept that many of their interests can only be satisfied by processes that transcend national borders.

\section{Regional integration may be peaceful and voluntary, but it is neither linear nor exempt} from conflict. The neo-functionalist strategy (also known in Euro-speak as "the Monnet Method") involves focusing as much as possible on low visibility and less controversial issues that can be separated from normal, i.e, party, and politics. As interest conflicts arise, they are decomposed and then recomposed into so-called "package deals" that promise benefits for all and compensate the prospective losers with side-payments in other domains. Regardless of the formal rules, even now that qualified majority voting applies to a wider and wider range of issues, every effort is made to reach a consensus. When such a solution cannot be found, the decisionmaking aspect of the integration process simply goes into hibernation for an indeterminate length of time. Meanwhile, the processes of expanded exchange continue to produce their intended and unintended effects and, eventually, the participants return to the table. The most visible aspect of the process has been the periodic negotiation of new treaties. Important as these may be, they are but the surface manifestation of a much more extensive process that has facilitated exchanges between individuals, firms and associations in virtually all domains of social, economic and political life and resulted in the creation of a large number of public and private organizations at the European level. Whether this strategy can persist is highly problematic. The EU has run out of low visibility arenas for policy coordination and the issues that it is currently facing, e.g. fiscal harmonization, visa and asylum requirements, police cooperation, common foreign and security policy, can be quite controversial. The increasing difficulty with the ratification of treaties that have been approved by all member governments is a clear sign of "politicization" and its penetration of domestic partisan politics.

\section{Regional integration should begin with a small number of member states, but should from that beginning announce that it is open to future adherents. Moreover, it is desirable that this initiating group form a "core area" to use Karl Deutsch's term; that is, they should be spatially contiguous and have a high rate of mutual exchange amongst themselves. If the functional area and members are well chosen, this should result in a differentially greater increase in exchanges among themselves and a discriminatory treatment of those who have been left outside. Provided that they agree on the internal distribution of benefits and do not generate permanent factions (not an easy task), their relative "success" will attract those neighboring states that chose initially not to join the region. The process of incorporating new members places a heavy burden on institutions, but becomes a manifest symbol that the "region" is worth joining. Especially crucial is the ability to protect the acquis when enlarging and not to dilute the accumulated set of mutual obligations as a way of satisfying specific interests in the new member states. It is important to remember that "regions" do not pre-exist in some cultural, social or economic sense. They have to be created politically out of existing "raw material."}

\section{Regional integration inevitably involves national states of quite different size and power} capability. Since it is a voluntary process, the largest and most powerful members cannot simply impose their will — as they would do in an imperial system. They have to respect the rights and presence of the smaller and weaker units. At a minimum, this implies firm guarantees for their continued existence, i.e. that the integration process will not involve their being "amalgamated" into larger ones, and this seems to require that smaller units be systematically over-represented in regional institutions. Moreover, there is a distinctive and positive role for smaller states to play in the integration process, especially when they can act as "buffer states" between larger ones. Not coincidentally, the citizens of those states that were smaller and less developed when they entered the EU tend to be among the stronger supporters of the EU. 
7. Regional integration, however, requires leadership, i.e. actors who are capable of taking initiatives and willing to pay a disproportionate share of the cost for them. The European experience suggests that this role is better played by a duopoly (France and Germany) rather than either a single hegemonic power (Germany) or a triopoly (Germany, France and Great Britain). Moreover, it is crucial that these leading regional actors accept to under-utilize their immediate power capability (pace neo-realism and intergovernmentalism) in order to invest it in a long run strategy of legitimating the enterprise as a whole. Fortunately for the integration of Europe, the potential hegemon (Germany) had just suffered a disastrous defeat in war and pre-inclined to downplay its role. France, the ex-great power, has found this more difficult and its tendency to selfmaximize has repeatedly threatened the process of consensus formation.

8. Regional integration requires a secretariat with limited but potentially supranational powers. Not only must this organization not be perceived as the instrument of one of its (hegemonic) members, but it also must possess some degree of control over the agenda of the process as a whole. The EU Commission is composed of members selected by an obscure process, firmly rooted in nomination by national governments, but presumed once approved to owe their allegiance to the supranational integration process and, therefore, not to take instructions from the body that chose them. There is evidence that, however flawed the nomination procedure, the Commissioners do tend to acquire a "collegial" perspective and to act as supranational agents. Moreover, the President of the Commission can under admittedly unusual circumstances not only assert his monopoly over the introduction of new measures, but also play a proactive role in determining what these measures should be.

9. Regional integration requires that member states be democratic. This is a factor that virtually all theories of European integration have taken for granted - as did the earlier practitioners until in the early 1960s when the application of Franco Spain for EEC membership made them explicitly stipulate that "domestic democracy" was a prerequisite to joining. In the Treaty of Amsterdam (19??) this was extended to cover respect for human rights and the rule of law. Obviously, when transferring the lessons of integration "out-of-region," this can no longer be taken for granted. Virtually all other regions in the world have some non-democracies within them. There are (at least) three reasons why democracy is necessary: (1) Only governments that have strong legitimacy within their respective national societies can make the sort of "credible commitments" that are necessary for them to enter into agreements, to ratify them conclusively, and to monitor their eventual implementation. In the present context, "the only game in town" with respect to domestic legitimacy in Europe is liberal parliamentary democracy. (2) The presence of a democratically accountable government within all members is a supplementary assurance that none of them will resort to force in resolving disputes. Whatever temptation more powerful governments might have to extract concessions by threatening weaker recalcitrant members, it seems unlikely that this would be supported by their own citizens. (3) If the neo-functionalists are right, a key element driving the integration process forward will be the formation of transnational interest associations and social movements and their intervention in supranational policymaking. Only in national democracies will citizens have the freedoms needed to organize such forms of collective action and to create links with others across national borders. The fact that, until the recent enlargement, all of the member states were not only democratic, but practiced a similar form of parliamentary democracy (except for France with its "semi-presidential" system) does not seem to have been important-if only because they also had quite different party and interest group systems, not to mention governments of the Left and Right. 
10. Regional integration seems possible with members that are at different levels of development and per capita wealth. At the beginning, in the EEC only Italy was markedly poorer and less developed. The subsequent incorporation of Ireland, Greece, Portugal and Spain reconfirmed the EU's capacity not just to accommodate to this obvious source of tension, but also to react to it. Through a combination of policies - selective derogations at entry, regional and structural funds, agricultural subsidies and the sheer dynamics of wider competitive markets-it promoted a pattern that could be called "upward convergence." Those member states (and even their less developed and poorer sub-national regions) that entered under less favorable conditions tended to do better subsequently and their standards of living have converged toward the EU norm (and, in one case (Ireland), even exceeded it)—without, however, noticeably depressing the performance of the more favored member states. The recent addition of 10 members is going to test this fortunate pattern severely. The initial differences in poverty and underdevelopment are greater than in past enlargements and, in some cases, this is compounded by structural differences in managerial and property relations rooted in the transition from "real-existing" socialism to "realexisting" capitalism. Nevertheless, contrary to the doctrinal assumption that integration into an enlarged market would inevitably widen the gap between wealthy and poor units — vide the national histories of Italy and Spain - so far, the EU has proved the contrary. Regional integration can not only cope with national economic differences at the point of departure, but also diminish them over time.

11. Regional integration is basically an endogenous process, but it can be critically vulnerable to exogenous forces, especially in its initial stages. Once a subset of national states has agreed to create a "region" by accepting certain mutual obligations and endowing a common organization with specified powers, its subsequent success or failure is primarily a matter of exchanges between these member states, plus the influence of non-state actors within and increasingly across their borders. Obviously, the more the initial powers delegated to the regional organization, the more important will be the role of its leadership and administration. The European experience, however, suggests that in its early stages regional integration can be very dependent on external powers. More precisely, it is doubtful that the process would have even begun with the Coal and Steel Community in 1952 and the Economic Community in 1958 without the benevolent intervention of the US. Here is where the "realist" perspective and its "intergovernmental" cousin should be especially relevant. Presumably, there exists a configuration of power and interest in the broader world system that determines if and when an exogenous hegemonic actor will conclude that it would prefer that its rivals be integrated rather than disintegrated. On the face of it, this seems contrary to the classical doctrine of "divide et imperum," i.e. the stronger you are, the more you wish that your opponents are divided-lest they gang up to countermand your dominance. Obviously, the overriding imperative in the case of Western Europe in the 1950s was fear of the Soviet Union. But now that this imperative no longer exists (and has not yet been replaced by fear of China), the implication seems clear: the US will be much less likely to view favorably movements toward regional integration - at least, those that it does not participate in or cannot control.

12. Regional integration, at least until it is well established, is a consumer not a producer of international security. To make sense of this affirmation one has to make a distinction between regional defense pacts and regional integration organizations. The former, usually the product of a hegemonic power that spreads its defense capability over that of subordinate others, e.g. the US and NATO, the Soviet Union and the Warsaw Pact, is exclusively oriented towards protecting the external sovereignty of its participants by military means; the latter's purpose is to supplant or, at least, to pool the internal sovereignty of its participants by removing barriers to economic, social and political exchange. In Western Europe, membership in the two was not coincident and definitely not obligatory. The $\mathrm{EEC} / \mathrm{EC} / \mathrm{EU}$ was no doubt fortunate in its early decades to have existed "in the shadow of NATO" and, therefore, not to have had to add external security to its 
already controversial agenda. With the collapse of the barrier between Western and Eastern Europe and the end of the Cold War, NATO's role has become increasingly ambiguous and EU member states have begun - against US resistance - to elaborate their own capability for collective security. Given the enormous difficulty of such a task, it has certainly been fortunate that their "civilian" regional institutions are already well established and recognized-if not always beloved. What is much more crucial for the success of regional integration is the existence among member states of what Karl Deutsch called a "pluralistic security community."7 This does not require common formal institutions, as would a viable military alliance (indeed, it can exist with allied and neutral members), but involves a firm and reliable, if informal, understanding that under no foreseeable circumstances will its members either use or threaten to use military force in the resolution of disputes among them. "Domestic democracy" in all member states is part of this mutual assurance (along with respect for the rule of law), but it is the daily practice of making deals and reaching consensus within regional organizations that makes this understanding credible.

\section{PART I II: HI STORY OF ASI AN REGI ONALI SM AND PROJ ECTS I N THE NEAR}

In the immediate aftermath of World War II, there was no serious discussion on or efforts at regional cooperation in Asia. The global Cold War structure, manifested in the systemic confrontation between the U.S. and the U.S.S.R., was rapidly unfolding. America's Cold War strategy in Asia, unlike the one in Europe, was not based on the concept and practice of collective security. Rather, it was predicated on a set of bilateral military alliances with Asian countries. Containment based on bilateral alliance structures was the most important foreign policy tool of the U.S. against the Soviet Union. As a result, instead of developing horizontal networks among themselves, Asian countries were far more closely aligned with and dependent on an extra-regional hegemon, namely the U.S. Meanwhile, Japan, which was to propose several important proposals for regional cooperation subsequently in the 1960 s, was still in the middle of postwar recovery and reconstruction.

From the neorealist perspective that positively correlates regional cooperation with the presence and influence of a powerful "hegemon," the lack of regionalism in Asia during the 1950s presents a puzzle. An extremely strong form of American hegemony - what is even described as "American relational predominance" -- existed unambiguously. But unlike in Europe where U.S. hegemony and leadership had been critically instrumental in engendering and promoting cooperative regional regimes and institutions, American hegemony in Asia rather inhibited regime formation and evolution. The newly established and quickly entrenched bilateral alliance structures prevented both Asian countries and the U.S. from seeking multilateral and collaborative solutions. The U.S., to retain "maximum influence over each of its Asian allies individually," resisted the creation of any intra-Asian regional ties. Consequently, the Asian region as a whole was seriously divided and fragmented.

Into the $1960 \mathrm{~s}$, the situation slowly began to change. Japan offered a number of proposals for regional collaboration. In 1966 the Japanese government played an instrumental role in setting up the Asian Development Bank and convened the Ministerial Conference on Economic Development in Southeast Asia (MCEDSEA). The main goal of the MCEDSEA was to disburse Japanese aid to Southeast Asia, in exchange for general political support for Japanese foreign policy by these countries. In 1967 Japanese and Australian groups of business managers formed the Pacific Basin Economic Council (PBEC), initially open only to businesspeople from the five Pacific Rim countries but subsequently open to other Asian states. In the same year, Japanese Prime Minister Miki proposed a Pacific Free Trade Area (PAFTA). Although the PAFTA initiative did not get

7 Karl Deutsch et al., Political Community and the North Atlantic Area (Princeton: Princeton University Press, 1957). Also see Richard W. Van Wagenen, "Research in the International Organization Field. Some Notes on a Possible Focus", Princeton, NJ, Center for Research on World Political Institutions, Princeton University, Publication No. 1, 1952. 
wide governmental support, it was critically instrumental in assisting the PBEC. In 1968 the Pacific Trade and Development Conference (PAFTAD) was created. At the first PAFTAD meeting, Kiyoshi Kojima in Japan proposed the establishment of intergovernmental collaboration through an Organization for Pacific Trade and Development, which would bring together Japan, U.S., Canada, Australia, New Zealand, and ASEAN states. The PAFTAD served as an agency of socialization into the dominant ideas of mainstream, i.e., neo-liberal, economics.

Overall, however, not much came of Japan's numerous proposals for regional cooperation during the 1960s. Most of the initiatives were nongovernmental. Although nongovernmental forums were instrumental in fostering greater contact among economists and business circles in the Pacific, the 1960s' outcomes were "merely associational, not involving government in any significant way." As well, many Asian countries, particularly those countries that had been Japan's colonies during the prewar period, were excessively skeptical and suspicious about the intentions behind these Japanese proposals for regional cooperation and integration. Lastly, the U.S. was also not very enthusiastic about supporting Japan's efforts at regional collaboration.

Another notable development in Asian regionalism during the 1960s was the creation of the ASEAN in 1967. The ASEAN was different from other proposals in that it was not led by Japan and was a political-strategic grouping. From the very beginning, the ASEAN was subregional in scope and values. Composed of the countries in the SEAR, e.g., Brunei, Indonesia, Malaysia, Singapore, the Philippines, and Thailand, it focused its efforts on economic bargaining with outside powers and followed a political-economic strategy of dependence reduction through partner diversification. The values espoused by the ASEAN members reflected "Southern" opposition to "Northern" dominance by the U.S. and other advanced countries.

The 1970s witnessed vigorous expansion and deepening of efforts at Asian regionalism. Japan continued its phenomenal economic success and developed vast investment networks in Northeast and Southeast Asia. Japanese investments spurred the creation of trans-border production networks in such industries as textiles, light manufacturing, and raw materials. In addition, China began to open its economy. Militarily, China's subsequent incorporation into the global economy considerably lowered the security threat in the region. Economically, China's opening activated extensive trade networks involving overseas Chinese. In the end, two different versions of Asian regionalism emerged and prospered. One was organized under the auspices of Japanese keiretsu conglomerates operating in cooperation with the Japanese government. The other was promoted by overseas Chinese seeking to combine their business skills and financial resources in tightly held, medium-sized family-owned firms, with the vast natural resources, cheap labor and pent-up consumer demand of the PRC. These two versions of regionalism were largely complementary to each other and thus collectively deepened and enriched the process of cooperation and integration in Asia.

This process culminated in 1980 when Japanese Prime Minister Ohira took the lead, in cooperation with Australian Prime Minister Fraser, in proposing a pan-Pacific organization. Unlike many Japanese proposals during the 1960s, Ohira's idea was seriously considered in American political circles. The outcome was the Pacific Economic Cooperation Conference (PECC). Its first meeting, held in Canberra in September 1980, was attended by delegations from the U.S., Japan, Canada, Australia, New Zealand, South Korea, and the ASEAN members. In subsequent meetings, the PECC expanded country participation and established an information base for more economic cooperation. The PECC is a tripartite body including government officials participating in a private capacity, academics, and businesspeople. PECC committees have a wide range of task forces that investigate substantive issues and make reports to the governments.

The vigorous expansion of Asian regionalism continued throughout the 1980s, with Japan taking a leading role. But what was more important than Japan's investment and production networks was that it served as a model for the rest of Asia. Japan's outward-oriented strategy of economic development, primarily based on export industrial sectors, was extended to and emulated by the entire region. As a result, into the 1980s, several Japan-emulating Newly Industrializing Countries, such as the " 
Four Little Dragons" (i.e., South Korea, Taiwan, Hong Kong, and Singapore) emerged as new investors and creators of ever-expanding investment and production networks in Asia. Against the backdrop of chronic deficits and other economic difficulties in the U.S., "hegemonic decline" and "bigemony" (of U.S. and Japan) were seriously discussed.

The apex of the 1980s regionalism in Asia was the establishment of the Asia-Pacific Economic Cooperation (APEC) in 1989. This was largely due to Australian Prime Minister Hawke's year-long initiative beginning in 1988. Australian government hosted its first ministerial meeting in December 1989. Governmental and nongovernmental representatives from Japan, U.S., Canada, South Korea, Australia, New Zealand, and ASEAN members participated in this meeting. Later, PRC, Taiwan, Hong Kong, Papua New Guinea, Mexico, and Chile also joined. With a budget of two million dollars and a small secretariat in Singapore, the APEC was considered to be the symbol of Asian regionalism during the 1990s.

In the 1990s, Japan's leadership in Asian regionalism was considerably eroded. Instead, the U.S., which had been rather passive so far about regional cooperation and integration, came to take a more assertive role. The U.S. rejected the Mahathir proposal in 1990 for East Asian Economic Group (EAEG). The EAEG, an alternative to APEC, was intended to include eleven Asian members of the APEC and to exclude the U.S., Canada, Australia, and New Zealand. By rejecting this proposal, the U.S. made clear that it would not allow an Asia-only process of regionalism. Later, the EAEG was downgraded to the East Asian Economic Caucus (EAEC) within the APEC. The Clinton administration also opposed calls for an Asian Monetary Foundation, demonstrating that the U.S. was interested only in using regional regimes and institutions to promote its own liberalization agenda in Asia. This significantly changed the nature and function of the APEC. The APEC had originally proposed two goals: Trade and Investment Liberalization and Facilitation (TILF) and development cooperation for developing economies in Asia. Up until the 1996 meeting in Manila, these received relatively balanced attention. However, the APEC gradually but noticeably shifted attention to TILF at the expense of development cooperation. This was largely due to the U.S. pressure. The Seattle summit in 1993 adopted a Trade and Investment Framework and created a permanent committee to replace the Informal Group on Trade Liberalization. After the Seattle meeting, the APEC put exclusive focus on the liberalization agenda and abandoned development cooperation altogether. This generated resentment among some Asian countries that viewed regional market liberalization as a device exclusively serving the interests of its richest members.

The U.S. push for liberalization in the end brought about the Bogor Declaration in 1994, which set trade and investment liberalization targets for 2010 for developed economies and 2020 for developing economies. The Bogor Declaration would not have been possible without the active facilitation of the U.S. On the surface, Indonesia exerted strong leadership to push the process, but behind the curtains the U.S. skillfully orchestrated the entire process to avoid resistance from developing economies. The 12th APEC ministerial meeting (and 8th Summit meeting) in Brunei in 2000 focused on the signing of a free-trade agreement among member economies and the resumption of a new round of negotiations with the WTO. Thus, primarily due to American pressure and assistance, the APEC became the main locomotive for liberalization in the AsiaPacific region and a building bloc for the liberalization of the world economy.

The crucial test for the APEC and other regional institutions in the region came with the Asian economic crisis of 1997-98. The responses of existing regional institutions to the crisis were very disappointing. Measured in terms of 1) premonitions of impending danger, 2) coordinated policy responses, 3) use of a collective voice to influence actors outside the region, and 4) "institutional innovations," Wesley (1999) reports that the role of Asian institutions (e.g., ASEAN, APEC, ADB) was minimal and ineffective in mitigating the economic downturn or promoting recovery. This contrasts with other regional institutions. For instance, "[b]oth NAFTA and the EU were able to demonstrate a solidarity, a resolution, and a commitment to the recovery of afflicted economies." As we will examine in more detail in Section V, the economic crisis in 1997-98 brought about an important disillusionment on the part of Asian countries with their existing regional regimes and institutions. But behind this disillusionment lies an even more fundamental 
skepticism with regard to the role of U.S. in Asian regionalism. The U.S. had manifestly instrumentalized the APEC to promote its agenda of liberalization and that, in the view of many Asian countries, had significantly eroded the legitimacy and effectiveness of regional institutions. All this prompted these countries to search for alternative arrangements in the post-crisis period.

So, where does that leave Asian regionalism now? One of the most important consequences of the economic crisis is that APEC has been considerably marginalized. Instead, Asian governments are concentrating their efforts on bilateral arrangements such as subregional free trade agreements. Japan signed a FTA agreement with Singapore in 2001 and has been aggressively pursuing a FTA agreement with South Korea. China announced that it would complete a free trade agreement with ASEAN within ten years. Several other bilateral free trade agreements have been reached or are currently being negotiated, including the Japanese-Singapore Economic Partnership Agreement, the China-ASEAN free trade process, and the Japanese-ASEAN Comprehensive Economic Partnership.

Another important development is the APT (ASEAN plus Three; ASEAN-10 plus China, South Korea, and Japan). The APT process began in 1997 when ASEAN invited the leaders of China, South Korea, and Japan for a first summit meeting. It is the most important institutional expression of the new Asian regionalism. APT is a consultative process involving thirteen governments. It has no independent secretariat yet, and the ASEAN secretariat provides logistic support. APT depends on bureaucrats in individual ministries of member countries who normally also manage APEC, ASEM, and its associated track-two activities. One of APT's commissioned groups, the East Asia Vision Group (EAVG), originally proposed by Kim Dae Jung, chaired by Han Sung-joo, and composed of two nongovernmental representatives selected by each of the thirteen countries in the APT, held five meetings between 1999 and 2001 and submitted a final report to the APT Summit in Brunei. EAVG's task was to identify the ultimate objectives of East Asian cooperation and how these objectives could be achieved. EAVG's successor is the East Asia Study Group (EASG), a collection of senior officials from each of the thirteen member states. After four meetings, it issued a report to the APT Summit in Phnom Penh in November 4, 2002.

All in all, the most obvious paradox of regional integration in Asia is, on the one hand, the multiplicity of rival but overlapping conceptions of which countries should be in which region and, hence, the large number of organizations that purport to represent different regions in Asia. On the other hand, none of these organizations seem to be more than mere acronyms that meet occasionally, discuss ambitious plans and, yet, never manage to endow the respective regional secretariats with the financial or administrative resources that would allow them to play an autonomous role. We suspect that no other region in the world has been carved up into so many transnational units and, yet, has so little capacity to act collectively. ${ }^{8}$

Now, there is nothing unique about this. In its early days, Europe also had several competing projects, although virtually from its conception the (then) EEC acquired a clear predominance and no one today questions that, whatever "Europe" will become as a region, the EU (or its successor organization) will play the major role in defining it.

The paradox of Asian regional integration also prevails in the NEAR. In recent decades, there have been several projects for this sub-region, but to date they have achieved very little. A few new proposals are currently being put forward, but it is too early to predict their future prospects. Here are four of these NEAR projects currently under discussion.

1. Tumen River Area Development Programme (TRADP): China, Russia, Mongolia, North Korea, and South Korea, under the auspices of UNDP, agreed to develop a special economic zone and related infrastructural facilities on the lower part of the Tumen river, in the international border area of China, Russia, and North Korea. The short-term goal of the project was to promote trade and investment in the area, and the long-term goal was to establish

8 One German scholar, Patrick Ziltener, even entitled a major paper: "Gibt es einen regionalen Integrationsprozess in Ostasien?" Köln: MPIfG Discussion Paper 03/3 (January 2003). 
transportation and distribution networks linking the Eurasian continent and the Pacific Ocean. At the $6^{\text {th }}$ Program Management Committee (PMC) meeting of the TRADP in December 1995, two international agreements and one memorandum of understanding were signed. Having created a Commission, a Committee, and a Secretariat, the project began to take shape as a multilateral cooperative institution. But the 1997 Asian Economic Crisis substantially weakened the momentum for the TRADP, and North Korea, TRADP's key member, rapidly lost its interest in the project due to various problems in domestic and foreign relations. With the June 1999 meeting in Mongolia at which new proposals for establishing investment networks and exploring new funding sources were made and with North Korea's resumed participation in the $6^{\text {th }}$ intergovernmental meeting in June 2002, the TRADP regained its momentum. The plan for the third stage of the program (2001-2003) was finalized and signed. However, the progress since then has been very slow. The most serious problem is lack of funding. Various ideas such as establishing a financial institution-e.g., the Northeast Asia Development Bank or the Tumen Region Development Facility_or including a rich new member such as Japan have been suggested and discussed, but none of them has materialized yet. As well, uncertainties about North Korea's ability and willingness to reform its economy and participate in the TRADP have continued to obstruct the progress of the project.

2. Korean Energy Development Organization (KEDO): Under the Geneva Agreed Framework between the US and North Korea, the US agreed to create an international consortium to provide North Korea with two 1,000 megawatt lightwater reactors and 500,000 tons of crude oil per annum, in exchange for North Korea's suspension of its nuclear development program. An international consortium, KEDO, consisting of South Korea, Japan, and the US, was established on March 9, 1995. Later, in implementing items in the Agreed Framework, the KEDO was expanded to include dozens of other countries in Asia, Europe, Oceania, and Americas. Numerous legal and institutional mechanisms and procedures for implementation were discussed, introduced, and established. However, from its inception, the implementation of the KEDO project was heavily dependent and predicated on the suspension, and eventual termination, of North Korea's nuclear program. The relations between North Korea and the US worsened precipitously after the inauguration of the Bush administration, 9-11 attacks and their aftermath, and the revelation of North Korea's HighlyEnriched Uranium (HEU) nuclear development program. As a result, the KEDO is now defunct and has suspended its activities.

3. Transcontinental Railroad Projects: The South Korean government is currently exploring four different possibilities for transcontinental railroad projects: Trans-Siberian Railroad (TSR), TransManchurian Railroad (TMR), Trans-Mongolian Railroad (TMGR), and Trans-Chinese Railroad (TCR). Countries concerned include Russia, Khazakstan, China, Mongolia, North Korea, and South Korea. Each railroad project has different routes, passing through different numbers of countries (ranging from two to four), involving different actors, incurring different amounts of time and money, and bringing about different kinds of effects on participating actors. The crucial factor to consider is that all these railroad projects presuppose the reasonable development of North Korea's railroad system and the resultant establishment of the Trans-Korean Railroad (TKR) system. Actors have expressed divergent interests. Russia is very much interested in the TKR-TSR project, with a view to eventually developing natural resources in Siberia and boosting the economy of Russian Far East. Russia is also most enthusiastic about modernizing North Korea's railroad system, which will be connected to TSR. Meanwhile, China is interested in developing its underdeveloped areas such as the three northeast provinces or the western region. It would welcome the modernization of North Korea's railroad system but is not interested in making big investment in the project.

4. Other Energy Cooperation Projects: Numerous plans for energy cooperation are currently being discussed and pursued. One proposal is to develop natural gas fields and establish pipelines in Eastern Siberia, so Korea and China can import natural gas at lower prices. South Korean, Chinese, 
and Russian companies agreed to develop gas sources in Irkutsk and its vicinity and connect pipelines to South Korea, China, and Russia. To complete this project, however, it is necessary, once again, to get active cooperation of North Korea, because the pipelines must pass through North Korea to reach South Korea. Peace-building in the Korean peninsula is therefore essential. Another proposal is to connect electricity grids in the two Koreas and Russia. In South Korea, electricity overloads mostly happen in the summertime, whereas in North Korea and Russia, they take place in the wintertime. Connection of electricity grids between Russian Far East with the two Koreas is being proposed to take advantage of different electricity consumption patterns to export surplus electricity to the other countries.

\section{PART I V: EU VS. NEAR—REFLECTI ONS ON THE THEORI ES AND THE LESSONS}

In Parts I and II, our analysis was resolutely Euro-centric. Our (disputable) presumption has been that, if the NEAR is to become integrated, it should learn from and follow the European pattern. Moreover, we have (surreptiously) defined integration in European terms, i.e. the process of "... how and why they (national states) voluntarily mingle, merge and mix with their neighbors so as to lose the factual attributes of sovereignty while acquiring new techniques for resolving conflicts

among themselves." 9 To this classical definition by Ernst Haas, we would only add that they do so by creating common and permanent institutions capable of making decisions binding on all members. Anything less than this - increasing trade flows, encouraging contacts among elites, making it easier for persons to communicate or meet with each other across national borders, promoting symbols of common identity - may make it more likely that integration will occur, but none of them is "the real thing."

Under these presumptions, as shown in Part III, both Asia and the NEAR have made very little or no progress toward integration. There have been moments of regional cooperation, solidarity and identification, but they have not created an institutional legacy of much significance, nor have they succeeded in diminishing those "factual attributes of sovereignty" that Haas mentioned. Only by challenging and changing the definition of what constitutes regional integration can it be said that progress has been made in this part of the world.

Several authors have made exactly this claim, namely, that there is a distinctive "Asian" pattern of integration that may not resemble the European "institutional" one, but nevertheless is capable of resolving regional problems, asserting regional cohesion and building regional identity. We disagree. We think this is a misleading overextension of the definition of "regional integration." Regional integration should be conceptually differentiated from simple-i.e., un-institutionalized and usually erratic) regional cooperation or collaboration.

Assuming that regional integration is desirable in NEAR, but has made minimal progress so far, we in this section present a number of reflections on the existing theories of European integration (Part I above) and on European "lessons" (Part II above), with a view to developing and offering a specific proposal that might promote successful regional integration in the NEAR in the near future.

\section{Reflections on the Theories}

Federalism is not likely to apply to the NEAR for several reasons:

1. All potential member states are not democracies;

2. All potential member states are not effectively "constitutionalized," nor is the rule of law evenly observed;

9 Ernst B. Haas, "The Study of Regional Integration: Reflections on the Joy and Anguish of Pretheorizing," in Leon N. Lindberg and Stuart A. Scheingold (eds.), Regional Integration: Theory and Research (Cambridge, MA: Harvard University Press, 1971, p. 6. 
3. All federations require a "core" of stateness, and none of the prospective members is prepared (yet) to concede such powers to the regional government;

4. So, the threshold is simply too high. Only after fifty years of intensive cooperation and very extensive interdependence have the EU member states agreed to even begin to discuss the "F-word" and they are still far from agreeing on its concrete institutions.

"Regulation-ism" will not be an option for the NEAR either for the following reasons:

1. "Regulation-ism" only becomes relevant once the level and extent of economic and social interdependence is very high and Northeast Asia is still very far from either;

2. Given the greater dependence upon "extra-regional" powers, the Northeast Asian countries are more likely to be compelled to conform to standards and norms elaborated and imposed by these "hegemons," i.e., by the US and the EU, or to become members of global "regimes" such as WTO and IMF.

3. Regulatory politics across national borders depends heavily on three factors, none of which are consistently present across Northeast Asia: (a.) Observance of the Rule of Law; (b.) Relative autonomy and professionalism of State bureaucracies;

(c.) "Epistemic communities" of specialized experts who share initial premises and operative procedures;

4. The efficacy of regulatory agencies, at least in democratic countries (and in autocratic ones, the agencies rarely have sufficient autonomy in the first place) depends crucially upon their being embedded in a broader context of political legitimacy that allows these non-democratic groups of experts to take decisions binding on everyone because they can be held accountable by independent parliaments, commissions of inquiry, a free press and partisan competition. None of these properties is evenly distributed throughout Northeast Asia.

This leaves us with two potentially viable options for regional integration: intergovernmentalism and neo-functionalism. Both have their problems and using either strategy will certainly be problematic in Northeast Asia, although our tentative assessment is that the former is less promising for the following reasons:

1. The "classic" (and apparently easiest) starting point for intergovernmentalism would be a "Free Trade Area (FTA)" or, even more ambitiously, a "Customs Union (CU)":

a. FTAs and CUs are notoriously difficult to negotiate sector by sector. They usually incorporate lots of derogations and exemptions, and the disputes they raise drain away most of the enthusiasm and integrative momentum.

b. Moreover, in the present global context where trade liberalization is on the broader agenda of organizations such as the WTO, there are only very limited benefits to be gained (also, thanks to the "most-favored-nation clauses" in many bilateral trade treaties).

c. And the "victims" of regional trade displacement are concentrated and often wellconnected politically; whereas, the "beneficiaries" are quite dispersed and much less wellorganized.

d. The "logic" of FTAs (but less so CUs) is to include as many "regional" partners as possible - e.g., ASEAN + 3-while the logic of effective regional/international integration is to concentrate on a small number of initial participants and to share the benefits among them first — and only later to expand.

e. There is no convincing historical evidence that FTAs tend to become CUs and then turn into Monetary Unions or Common Markets. Regional experiments with FTAs in Central America, South America and North America suggest that - if they survive at all — they do so by encapsulating themselves and not by spilling-over into wider arenas of policy-making. They may be easy to adopt (if sufficiently riddled with exemptions), but they are very unlikely to expand into monetary affairs or greater labor mobility or even to extend their "lessons of cooperation" into less closely related policy arenas. 
f. FTAs seem to be particularly susceptible to problems with the size distribution of member states. The larger ones with greater internal markets are almost always accused of exploiting the small ones-especially in the "uneven" exchange between manufactured goods and raw materials. When size distribution lines up with level of development, i.e., when the largest member states are also the richest, the conflicts generated become even more difficult to manage;

2. Intergovernmentalism does not depend upon all the governments involved being of the same regime type - that is one of its major advantages for Northeast Asia — but it is sensitive to the contradictory role of hegemon. On the one hand, it (or they, if there is some sort of co-hegemony such as has existed with France and Germany in the EU) has to be interested in taking the lead and paying a disproportionate share of the costs; on the other hand, it/they must be very careful not to be perceived as exploiting the others once the FTA or whatever other agreement is reached and has begun to generate its inevitably unequal flow of benefits. Why, then, should the hegemon when it presumably could dominate a given region and just impose its preferred rules choose deliberately to underutilize its power resources and concede so much to its minor partners?;

3. Inter-governmentally based regional arrangements, provided they remain inter-governmental, are not very likely to lead to spill-overs and, hence, further integration - unless some external shock or exogenous condition intervenes. If governments only enter into such arrangements voluntarily and rationally, i.e. when they are fully conscious of their costs-and-benefits and have excluded all possible unintended consequences, they are highly unlikely to react to unsatisfactory performance or unequal distributions of benefits by agreeing to up-grade their commitments and draft a new more expansive treaty. Their response will probably be either to freeze their existing level of commitment or to withdraw from the arrangement altogether-which, of course, as sovereign national states they are by definition capable of doing.

So, our tentative assessment that intergovernmentalism is not so much impossible to imagine in Northeast Asia as much less consequential with regard to eventual regional integration. It would be relatively easy to accomplish in formal terms - treaties supposedly establishing free trade areas have been signed relatively frequently within and across world regions. But it would not make that much difference. Many of those free trade agreements were never implemented and when they were they rarely, if ever, lead to highly levels of regional integration, which leaves us with neo-functionalism as the most promising, if not the most feasible strategy for promoting Northeast Asian regionalism.

\section{Reflections on European "Lessons"}

1. Regional integration is a process not a product. In pursuing regional integration in the NEAR, as was the case with European integration, we should never assume that we know where we are heading. Not just la finalité politique but also fles finalités economiques ou sociales are completely unknowable. The process of regional integration is uncertain and unpredictable. However, it must be peaceful, voluntary, and, most importantly, transformative. The process must change national states' motives and calculations, enlarge the functional tasks they accomplish collectively, expand the authority and capacity of supranational institutions, and stimulate interest associations and social movements across member states. In this regard, one of the major problems with FTAs, which are currently so popular in the NEAR, is that they "seem" to be and may indeed be "selfcontained." FTAs are very unlikely to generate any of the above effects that a process of integration is expected to produce. Moreover, most of the goals that FTAs are intended to achieve are already being accomplished through GATT and WTO. In short, "regional" FTAs are not so regional any more. So-called "open" regionalism based on a series of FTAs does little or nothing to promote integration. 
2. Regional Integration has to begin somewhere and the best place to do so under contemporary conditions is with a functional area that is of relatively low political visibility, that can apparently be dealt with separately and that can generate significant benefits for all participants. For regional integration to proceed, it is essential to promote collective resolution of concrete problems in a positive fashion. That is the main lesson proffered by the original functionalist theorist of integration, David Mitrany. ${ }^{10}$ From the very beginning, the integration should be not just about removing barriers (negative integration), but also about creating common policies to regulate and distribute benefits ("positive" integration). ${ }^{11}$ With regard to the distribution of benefits, the best one, of course, is Pareto optimal when everyone wins and no one loses. But this is highly unrealistic. The distribution of benefits can be (and almost always is) disproportional at times, but it is critical to ensure a proportional or "fair" distribution over a longer period. Participating actors must be encouraged to think in terms of absolute rather than relative gains. It is extremely critical to select a functional area that is initially uncontroversiality "separable," and "interconnected" "Separable" means that the area must be capable of being dealt with apart and of generating sufficient benefits on its own. "Interconnected" means that the area must be capable of generating secondary effects that require attention and engendering positive supportive coalitions across borders. Trade liberalization, including the FTAs discussed and pursued in the NEAR, is a form of "negative" integration and is unlikely to produce "spill-over" effects and to contribute to regional integration. Furthermore, FTAs generate too much resistance and opportunity for cheating and weaseling.

In the specific case of the NEAR, it will be critical to find the contemporary equivalent of "coal and steel" which is where the EU began in the early 1950s. This could be transport (one functional area) or, better, transport and energy (two highly interrelated functional areas). In the abstract, transport and energy seem to satisfy all the above-mentioned conditions, i.e., relatively low controversiality, separablity, and interconnectedness, although given the 'sensitive' nature of the North Korean regime no functional area may be without its controversiality. It is in this respect very encouraging that some of the previous projects and current plans for regional integration in the NEAR, such as transcontinental railroad and energy development projects, are focused on these two functional areas.

\section{Regional integration is driven by the convergence of interests, not by the formation of an} identity. International regions do not exist, even where created and administered as such by a colonial power. Common language and religion do not seem to be of much help. Rather, they may even be a hindrance where they hide different "sects" of the same religion or dialects of the same language. We should be equally careful about the economists' notion of complementarity. Regional integration is an intrinsically dynamic process and generates unforeseen and emergent specializations and new divisions of labor among its participants. Hence, pre-existing trade patterns may not be a good indicator of the potential for generating new forms and levels of interdependence.

It is also important that nation states join with convergent-but not identical-motives. They should "hit on" integration for different reasons and with different expectations. This provides the future potential for making 'package deals' that will include a variety of pay-offs across participants. Also, there seems to be no automatic effect (a la Karl Deutsch) on integration of substantial increases in social communication across national borders. Decreases in communication may lead to separate identities, but increases do not produce integration. Contrary to the common notion, previously intense national antagonisms can be useful for integration - provided there is a strong motive for overcoming them (usually due to the existence of a common enemy). Something approaching a Northeast Asian identity has certainly emerged after the 1997-98 Asian economic crisis, largely in protest against the hegemony of the US and the dominance of the American

10 A Working Peace System (Chicago: Quadrangle Books, 1946). Originally published in 1943.

11 Scharpf, F. W. (1996). "Negative and Positive Integration in the Political Economy of European Welfare States," In G. Marks \& F. W. Scharpf \& P. C. Schmitter \& W. Streek (Eds.), Governance in the European Union (Thousand Oaks, CA: Sage), pp. 15-39. 
developmental model. ${ }^{12}$ However, there is little evidence that this new identity is pushing forward regional integration. Identity or loyalty to the region as a whole is the eventual product of, not the pre-requisite for, integration. A lot, in other words, can be accomplished before a common identity or loyalty emerges.

\section{Regional integration may be peaceful and voluntary, but it is neither linear nor exempt} from conflict. All the participants from the beginning must acknowledge the existence of conflicts. But this is not enough. They must also expect those conflicts to be resolved peacefully. Indeed, the existence of conflicts is inevitable and exploitable. Without conflicts, regional integration would not advance. Of much greater importance is the answer to the question: What is the method for resolving these conflicts? Who "cooks up" the winning formula? One of the tricks transferable from the European experience is to use the conflicts (usually over inequality in the distribution of benefits) to expand not to contract the scope and level of common (supranational) regional authority. Many (but not all) conflicts can only be resolved by increasing the powers of regional secretariat or expanding the scope of common activities (or both) with side-payments to losers. The unanimity rule is crucial at the early stage to reassure potential losers (especially if they are very unequal participants), but tends to be transformed as the integration process advances. In the NEAR, where there are both democracies and non-democracies, it is especially pivotal to build and develop relations of mutual trust among member national states so that a firm confidence in the peaceful resolution of conflicts can be fostered and nurtured. Cultural and track II exchanges aimed at enhancing mutual understanding may help to build such trust.

\section{Regional integration should begin with a small number of member states, but should from that beginning announce that it is open to future adherents. The EEC originally started with six members, but was open to others. It should not be presumed that initial exclusion is definitive, although it is useful to have small number in the beginning for decision-making and distributive purposes. Demonstration of "success" through subsequent enlargement is crucial. In choosing member states, there are two factors to consider: spatial contiguity ("core area") and relatively high initial exchange ("relative acceptance ratio"). The latter is important because it increases the "envy" of outsiders. The unanimity rule, along with tolerance, should be enforced when admitting new entrants. As well, deliberate ambiguity about "regional" boundaries is sometimes useful. The NEAR has only six members in total (Russia's Far East, China, Mongolia, North Korea, South Korea, and Japan). If there is a functional area that can involve all six, integration could begin with all six national states as members. Otherwise, a subset of two or three geographically contiguous and relatively accepting countries (e.g., North and South Korea) can initiate a project and then expand it to involve the other countries as the process advances. As regional integration deepens, the NEAR might even be extended to include countries in the SEAR too.}

\section{Regional integration inevitably involves national states of quite different size and power} capability. The key interest cleavages in the process of integration tend to be based on relative size and level of development. These should be accommodated in institutional rules, e.g.. by overrepresenting small countries and inserting special programs for less developed members. There should be an implicit or explicit guarantee that regional integration does not mean assimilation of small members into large members, or less developed ones into the more developed. Quite the contrary is true: integration is often the best guarantee for the survival of small/less developed states. The best imaginable outcome is "convergence" where by the weakest members in economic and political performance find themselves growing fast and becoming more secure relative to those that are strong and stable. The thorny issue is how to ensure that the latter agree to such a re-distribution of income and power. One central role in this process should be played by the adjudication process at regional level (e.g., European Court of Justice). This will ensure that large actors do not

12 Sunhyuk Kim \& Yong Wook Lee, "New Asian Regionalism and the United States: Constructing Regional Identity and Interest in the Politics of Inclusion and Exclusion," Pacific Focus (October 2004). 
dominant small ones. Also, the secretariat of the regional organization should play a proactive role in controlling initiatives and making coalitions that combine both the weak and the strong. Symbolic compensation should be made through such devices as an equal number of commissioners and a rotating presidency of the commission. Also, an "insurance" policy should be issued not just against assimilation, but also against intra-national disintegration. Sub-national regions should be given only limited roles, and only with national approval. Also, obvious compensations can be made through location of regional institutions by over-favoring small states.

In the NEAR, the smallest (in terms of population) and poorest participant would be North Korea. As is clear from the past experience (discussed in Part III), North Korea's inability or unwillingness to cooperate has been and will continue to be the greatest hindrance to further progress in regional integration. Therefore, special measures must be taken to guarantee the survival of North Korea and to ensure that no attempts will be made to assimilate it to its southern "brethren." A symbolic compensation, such as locating major supranational regional institutions in North Korea, would be both necessary and desirable.

7. Regional integration, however, requires leadership, i.e. actors who are capable of taking initiatives and willing to pay a disproportionate share of the cost for them. This is obviously related to the preceding issue of size and development. In the fortunate European pattern, the two cleavages (size and development) do not coincide, but cut across each other. Some small countries are rich and some large ones are (relatively) poor. In the NEAR, the situation would be more complicated. Russia and Mongolia are large but (relatively) poor. China is large and rapidly developing. Japan and South Korea are small but rich. North Korea is (unfortunately) both small and poor. The important questions to be answered are: (1) Why will a hegemon or pair or trio of hegemons be willing to pay the higher price for membership; and (2) What can induce them to under-utilize their power advantage? In the case of a hegemonic duo, stability is important but sometimes brings awkwardness among late arrivers. A single "imperial" hegemon, even if "generous," can sometimes have an inhibiting effect-e.g., USA in NAFTA or Brasil in MERCOSUR. In the NEAR, a duopoly of China and Japan is unlikely for various historical and political reasons. South Korea can play a leadership role in regional integration, mediating between China and Japan. The current South Korean government is unprecedentedly enthusiastic about facilitating regional integration in the NEAR, empowering the Presidential Committee on Northeast Asia Initiative. Obviously, South Korea is not a regional "hegemon." Hence, an important theoretical question to be asked is whether a middle power such as South Korea will be able to play a leadership role in regional integration. Or is facilitator-ship (in contrast to leadership) sufficient for regional integration?

8. Regional integration requires a secretariat with limited but potentially supranational powers. Key powers of the secretariat, in the case of EU, include: (1) control over initiation of new proposals; (2) control over distribution of positions within its quasi-cabinet (the European Commission); (3) budgetary discretion; (4) potential to take member states to European Court of Justice; (5) network position and possible information monopolies, especially with regard to subnational actors (functional and territorial); (6) alliances with Euro-parliament; and (7) packagedealing and log-rolling potential. In the NEAR, so far all attempts at building a secretariat with supranational powers have failed. No regional institution has any of the powers listed above. Building and funding a supranational secretariat must be the first priority in any future project of regional integration in the NEAR.

9. Regional integration requires that member states be democratic. That member states are democratic provides insurance that members will not use force against each other, especially once integration has progressed and their respective civil societies have become intertwined. Some guarantees of government legitimacy and of a "centripetal/centrist" tendency in partisan competition are also essential so that commitments remain not only constant across parties, but also 
deeply rooted in citizen expectations. In the NEAR, there are two non-democracies (China and North Korea) and four democracies or quasi-democracies (Japan and South Korea, Mongolia and Russia). Moreover, the democracies are at different levels of regime consolidation. Hence, we cannot expect all the positive effects of "a union of democracies," as was the case in the EU. It should be noted, however, that the central paradox of regional integration is that it may require democracy, but in the initial stages these national democracies must not be too attentive or interested in the process. This suggests that -- at least at the beginning stages -- the existence of non-democracies might not necessarily be such a deplorable thing. Rather, regional integration could be initially promoted by cooperation between stable and predictable autocracies, as well as democracies, and as long as they trusted each other sufficiently to keep their commitments and not to resort to force or even the threat of force in resolving disputes. Subsequently, the spreading of integration to new areas and its deepening to include more powers for its secretariat may promote democratization across all member states.

10. Regional integration seems possible with members that are at different levels of development and per capita wealth. The European experience not only shows that regional integration is possible for member national states with different levels of development but also clearly demonstrates that upward convergence is possible for poorer and less developed countries. In other words, integration not only can cope with national disparities at the point of departure, but also diminish them over time. The NEAR consists of six countries at quite different levels of development and per capita wealth. The poorer and less development members of the NEAR must be persuaded and convinced that their participation in regional integration initiatives is the best and surest strategy to catch up and compete with advanced economies in the region.

11. Regional integration is basically an endogenous process, but it can be critically vulnerable to exogenous forces, especially in its initial stages. The European experience strongly suggests that in its early stages regional integration can be highly dependent on external powers. In particular, it is extremely doubtful whether the process would have even begun without the benevolent intervention of the US. In the NEAR, where the influence of the US has been far greater due to the Cold War generated, "hub-and-spoke" structure of bilateral alliances, the tolerance, understanding, agreement, and cooperation of the US would be essential for the success of any movement toward regional integration. So far, the US has been relatively inattentive or indifferent to various integration projects in the NEAR, including even those attempts in the aftermath of the Asian economic crisis that intentionally excluded the US. But it is rather unlikely that the US will continue such inattention and indifference to various regional integration initiatives in the region. In these circumstances, it is advisable to actively seek the comprehension and cooperation of the USespecially at the beginning stages of regional integration in the NEAR.

12. Regional integration, at least until it is well established, is a consumer not a producer of international security. For the NEAR, this is the most valuable lesson from Europe. The European integration was from the beginning predicated on the existence of a "security community" composed of democratic countries. The NEAR is starkly different from Europe in this regard: it includes non-democracies, and potentially violent conflicts abound among member national states. Animosities, both historical and present, clearly exist between North and South Korea, between Russia and China, between China and Japan, between Mongolia and China, between North Korea and Japan, between Russia and Japan, etc. Among these multiple conflicts, the most acute and urgent one involves the confrontation between the two Koreas. Without substantial decrease in the military tension between the two Koreas and the subsequent opening and reform of the North Korean economy, it is virtually impossible to pursue any fruitful regional integration projects in the NEAR, because North Korea, one of the key members in regional integration in the NEAR, will be either unable or unwilling to participate. Upsetting of regional international security by North Korea or any other country would be more than sufficient to suspend the integration process as a whole. 
International security within the region, in this sense, is not merely a facilitating condition but a strong precondition for the success of NEAR. Regional security, in turn, is impossible without resolving the North Korean nuclear issue, which inevitably assumes improved relations and eventual diplomatic normalization between North Korea and the US and the resultant establishment of a peace system on the Korean peninsula. In this regard, peace-building in the Korean peninsula (and the possible democratization of North Korea) is an integral building block for any form of integration in the NEAR.

\section{PART V: A PROPOSAL}

1. Select a functional task or two. The chosen task must be separable, manifestly difficult to realize within the confines of a single national state, and capable of generating concrete benefits for all participants with a relatively short period of time. Two functional tasks are better so that trade-offs can be negotiated across them.

1.1 This "separable" task must be sufficiently consequential so that, in satisfying it collectively, the actors will generate new difficulties in interrelated areas. This "spill-over" potential will be much easier to exploit if, in the original agreement, the participating national states will have agreed to establish a relatively autonomous and internationally staffed secretariat for a regional organization that has some minimal supranational authority, i.e. can take decisions without a constant need for the unanimous support of its member states.

1.2 "Spill-over" is also more likely if the tasks involve a variety of relatively autonomous and discrete state agencies - and especially not just foreign ministries who will normally try to monopolize intergovernmental transactions - and if these agencies are staffed by technical and not politically appointed personnel.

1.3. In the NEAR, the joint energy and transportation infrastructure seems to provide an appropriate and apparently separable set of "functions." These areas do not require any initial commitment to further integration, especially to FTA. The irony is that these two functional areas were among the very last ones in which EU was able to generate consensus.

2. Select a core area of contiguous units with internal lines of communication and exchange and, if possible, convergent motives for cooperation.

2.1 In the NEAR, considering the importance of North Korea's ability and willingness to cooperate, it might be a good idea to begin with only the two Koreas, but later invite the participation of China, Russia, Mongolia, and Japan. However, going ahead should not be conditional on their initially joining and one should be prepared for one or another of them to "opt out," as did Great Britain in the ECSC and the EEC. This $2+4$ strategy seems to be worth pursuing, even against the initial opposition of the other potential members.

2.2. Insist on the equal status and national sovereignty of all participants and discount any pretension to using this functional cooperation as the mechanism for unification. In other words, "regional integration" should be clearly separated from "national unification."

3. Distribute agencies so that bulk will be located in North Korea (although any financial agency should be in the South for obvious reasons of communicative efficiency), but with jointly staffed secretariat. 
4. Integration will also be enhanced if the initial task or tasks and the initial delegation or delegations of authority are sufficient to attract the attention of non-state interests and to provide incentives for them to form transnational interest associations or social movements and to demand access to the deliberations of the regional secretariat. Given the present condition of associations and movements in North Korea, this may be impossible to realize for some time.

5. Start low-key and low-visibility projects in order not to attract the wrath of the US, which will not in all probability be as "benevolently inclined" as it was in the case of ECSC and EEC. And, yet, seek to convince the US that such "low grade" efforts will eventually contribute positively to its broader goal of security within the region.

6. Be prepared to think about, but not incorporate, "the security dilemma." Northeast Asia is definitely not a Deutschian "Security Community"-neither was Europe in 1950-52 — but neofunctional integration is designed to improve the prospects for such a community-in the longer run.

7. Whatever the task or tasks and whatever the power or powers of the functional organization, integration will be enhanced to the extent that the national and regional actors involved:

a. Develop relations of mutual trust;

b. Enjoy enhanced status within their respective governments and in the wider international community;

c. Learn concrete problem-solving lessons from their cooperation;

d. Generate significant material rewards for both member governments and their citizens.

e. Finally, all member states must participate as formal equals in the functional agency - with which effectively means that smaller or weaker states must be over-represented. Even more importantly, the benefits from cooperation and increased interdependence should be informally distributed so that they do not accrue proportionately to the larger or stronger state or states - in other words, the hegemon or hegemons must be willing to subsidize the others, but not to do so overtly. 